\title{
IMPLEMENTASI PENDIDIKAN INKLUSIF SEBAGAI PERUBAHAN PARADIGMA PENDIDIKAN DI INDONESIA
}

\author{
Muchamad Irvan ${ }^{1}$, Muhammad Nurrohman Jauhari ${ }^{2}$, \\ Program Studi Pendidikan Khusus \\ Universitas PGRI Adi Buana Surabaya \\ irvan.mch@unipasby.ac.id ${ }^{1}$ \\ Muhammadnurrohmanjauhari@gmail.com ${ }^{2}$
}

\begin{abstract}
The aim of implementing Inclusive education is providing opportunities for all students to fulfill the right of children with disabilities that is to learn together with other students in a school environment. The implementation of inclusive schools should initiate an inclusive culture, and a friendly environment for children with disabilities. The writing of this article aims to examine the implementation of inclusive education in Indonesia. The data are processed, obtained through literature study, interview, and field observation. Data collected are analyzed using qualitative approach. The data obtained shows that the implementation of inclusive school has not been evenly distributed in every region, not have adequate accessibility yet, and not fulfillment of competent educator in special education field yet. Based on the analysis it can be concluded that the implementation of inclusive education requires the function of supervision, assistance, and evaluation to support the positive progress of inclusive education in terms of both quantity and quality.
\end{abstract}

Keyword: Inclusive Education ; Educational Paradigm

\section{PENDAHULUAN}

Lebih dari satu dekade terakhir pendidikan di Indonesia mulai digalakkan penerapan sistem pendidikan inklusif. Pendidikan inklusif menjadi isu terhangat kaitannya dalam rangka memberikan pelayanan atas hak anak-anak berkebutuhan khusus untuk mendapatkan pendidikan yang sama. Pandangan tersebut dijelaskan pasal 15 dalam UU SISDIKNAS Nomor 20 Tahun 2003 bahwa penyelenggaraan pendidikan untuk peserta didik berkelainan diselenggarakan secara inklusif atau berupa sekolah khusus.
Sebagai bentuk langkah kongkrit pemerintah dalam menyikapi layanan pendidikan inklusif, pada tahun 2009 diterbitkan Permendiknas No.70 sebagai tonggak penerapan pendidikan inklusif di setiap daerah.

Sesuai dengan pengertiannya, pendidikan inklusif diterapkan dengan tujuan untuk memberikan kesempatan terhadap seluruh peserta didik tanpa memandang ras, suku, agama, tingkat peroknomian, maupun yang memiliki kebutuhan pelayanan khusus. Namun dari pada itu, dari segi implementasinya pendidikan inklusif lebih diarahkan 
pada pemenuhan hak pendidikan bagi anak berkebutuhan khusus yaitu untuk belajar bersama dengan peserta didik lain dalam satu lingkungan sekolah. Sistem pembelajaran pada sekolah khusus diintegrasikan dalam sekolah reguler dimana setiap peserta didik regular dan peserta didik berkebutuhan khusus belajar, bermain, dan berinteraksi bersama dalam setting sekolah inklusi.

Berdasarkan sejarahnya, Indonesia mulai mengimplementasikan pendidikan inklusif pada tahun 2005 dengan diawali membangun sekolahsekolah inklusi percobaan. Tercatat pada tahun 2008 Indonesia mulai memiliki 814 sekolah inklusi yang tersebar di beberapa daerah (PKLK, 2011). Indonesia mulai menerapkan sistem pendidikan inklusif dalam setting sekolah inklusi berangkat dari permasalahan mendasar, bahwa kurang tersebarnya Sekolah Luar Biasa (SLB) sampai dengan pelosok daerah.

Permasalahan

tersebut menyebabkan program wajib belajar di Indonesia belum tercapai karena layanan pendidikan bagi anak berkebutuhan khusus tidak terpenuhi (Choiri dan Munawir, 2009). Harapannya, dengan diterapkannya pendidikan inklusif dapat memberikan layanan pendidikan bagi anak berkebutuhan khusus serta dapat mewujudkan tercapainya program wajib belajar.
Penulisan artikel ini bertujuan untuk mengkaji implementasi pendidikan inklusif di Indonesia. Data yang diolah diperoleh melalui studi literatur, wawancara, dan observasi lapangan. Data yang dikumpulkan dianalisis menggunakan pendekatan kualitatif. Kajian tentang penyelenggaraan pendidikan inklusif ini diharapkan dapat menyumbang pengetahuan dan keilmuan agar kedapannya dapat menjadikan pendidikan di Indonesia khususnya pendidikan inklusif semakin baik.

\section{PEMBAHASAN}

1. Esensi

Penyelenggaraan

\section{Pendidikan Inklusif}

\section{a. Tentang Pendidikan Inklusif}

Sejarah awal pendidikan khusus di Indonesia dikenal dengan terselenggaranya 3 jenis sekolah yaitu Sekolah Luar Biasa (SLB), Sekolah Dasar Luar Biasa (SDLB), Sekolah Terpadu. SLB adalah sekolah yang menyediakan layanan pendidikan hanya untuk satu kategori anak berkebutuhan khusus. Selain itu di SLB juga terdapat berbagai jenjang pendidikan dimulai dari jenjang TK sampai dengan SMA. Berbeda dengan SDLB yang hanya terdapat satu jenjang saja yaitu SD (Sekolah Dasar). Namun SDLB menyediakan layanan pendidikan pada semua kategori anak berkebutuhan khusus. Sedangkan sekolah terpadu adalah 
sekolah reguler yang menampung anak berkebutuhan khusus yang diberikan sarana dan prasana yang sama termasuk kurikulum pembelajarannya.

Program pendidikan terpadu pada tahun 1980-an merupakan bibit dari penerapan pendidikan inklusif di Indonesia (PKLK, 2011). Namun, kurang tepatnya proses penerapan program tersebut menjadikan pendidikan terpadu kurang diterima oleh kalangan masyarakat, sehingga seiring dengan berjalannya waktu program pendidikan terpadu mulai menghilang. Setelah munculnya "The Salamanca Statement on Inclusive Education" dari hasil deklarasi Salamanca di Spanyol pada tahun 1994, hampir setiap negara di dunia mulai menerapkan sistem pendidikan inklusif.

Pendidikan inklusif itu sendiri berasal dari istilah Inklusi. Menurut KKBI, kata inklusi memiliki arti sebuah ideologi untuk membentuk suatu lingkungan yang terbuka, dengan mengikutsertakan setiap orang tanpa memandang status sosial, ekonomi, karakteristik, kondisi tertentu, suku, ras, dan agama. Tentu kita dapat menggambarkan bahwasanya pendidikan inklusif merupakan pendidikan yang mengikutsertakan semua peserta didik tanpa memandang status apapun, termasuk karakteristik dan kondisi tertentu. Sehingga demikian setiap anak dapat belajar bersama dalam satu lingkungan sekolah dengan layanan yang sama untuk menumbuhkan lingkungan sekolah yang bersifat inklusif. Pendidikan inklusif merupakan suatu pendidikan terintegrasi di mana anak berkebutuhan khusus dapat berpartisipasi untuk memperoleh layanan pendidikan dengan sistem, metodologi, dan pembelajaran yang sesuai dengan kebutuhan dan kemampuannya (Abosi : 2008).

Namun demikian Smith (2006) menyatakan bahwa setting pendidikan yang bertajuk Sekolah Inklusi adalah sekolah yang mengikutsertakan anak-anak berkebutuhan khusus untuk terlibat dalam kegiatan pembelajaran dan menjadi bagian dari penerapan kurikulum, membentuk budaya lingkungan yang kondusif, serta membangun visi misi sekolah. Sementara itu Choiri dan Munawir (2009) juga menekankan bahwa sekolah inklusi harus tumbuh dengan budaya yang inklusif, dimana setiap warga sekolah baik masyarakat, guru, kepala sekolah, yayasan, karyawan, sampai dengan petugas administrasi bertanggung jawab semua dalam mendidik dan mengembangkan potensi yang dimiliki siswa. Selanjutnya Sapon- 
Shevin (dalam O'Neil, John; 1994) juga menyatakan bahwa pendidikan inklusif sebagai pendidikan khusus harus dapat melayani semua siswa berkebutuhan khusus dengan siswa lainnya secara bersama-sama dalam satu lingkungan sekolah.

Pernyataan-pernyataan

tersebut selaras dengan tujuan diterapkannya konsep sekolah inklusi di Indonesia, yaitu agar dapat mengikutsertakan anak berkebutuhan khusus belajar bersama peserta didik lain dalam satu lingkungan sekolah. Penerapan pendidikan Inklusif di Indonesia berawal dari kurangnya jumlah SLB yang ada di seluruh wilayah. Di setiap daerah, kabupaten maupun kota sebaran SLB hanya dalam jumlah hitungan satuan. Kondisi tersebut diperparah dengan letak SLB yang hanya terfokus di pusat kota. Hal ini menjadi fakta yang ironis jika kita menilai bahwa pemerintah memiliki program wajib belajar untuk setiap anak-anak di Indonesia.

Program wajib belajar tentu tidak tercapai jika SLB hanya terfokus di pusat kota, sedangkan di pedesaan tidak terjamah pendidikan khusus. Ketidaktercapaian tersebut dapat kita simpulkan dari kondisi masyarakat pedesaan yang memiliki tingkat perekonomian menengah kebawah. Menjadi masalah terbesar mengapa anak-anak mereka (anak berkebutuhan khusus) tidak dapat bersekolah yaitu jarak tempuh yang jauh, moda transportasi yang terbatas, kemudian dibutuhkan biaya yang besar untuk kebutuhan perjalanan. Berdasarkan kasus tersebut, pemerintah telah membaca permasalahan utama yang dihadapi untuk dapat memenuhi program wajib belajar. Oleh karena itu, pemerintah berinisiatif menerapkan kembali sistem sekolah terpadu dengan istilah baru yang sedang hangat di Eropa, yaitu Pendidikan Inklusif. Harapannya, dengan diselenggarakan sekolah inklusi dapat menjawab tuntutan wajib belajar bagi warga negara, khususnya untuk anak-anak berkebutuhan khusus.

\section{b. Aspek Pendidikan Inklusif}

Peserta Didik

Peserta didik di sekolah inklusi terdiri atas dua kelompok peserta didik. Pertama, peserta didik reguler yaitu peserta didik yang tidak memiliki hambatan atau disabilitas atau dikategorikan "normal". Selanjutnya, peserta didik berkebutuhan khusus yaitu peserta didik yang mengalami hambatan atau disabilitas pada perkembangan fisik, emosional, mental, sosial, atau memiliki potensi kecerdasan dan atau bakat istimewa. Kedua peserta didik tersebut berhak belajar dan 
mengikuti segala aktivitas pembelajaran di lingkungan sekolah secara bersama-sama dalam setting pendidikan inklusif (Nasichin, 2001).

Tenaga Pendidik

Terdapat 3 jenis tenaga pendidik dalam setting pendidikan inklusif. Setiap guru memiliki peran yang berbeda-beda dalam menumbuhkan budaya inklusif dalam proses pembelajaran. Adapun definisi 3 jenis guru tersebut adalah sebagai berikut.

a. Guru kelas

Guru kelas adalah tenaga pendidik/pengajar pada tingkatan kelas tertentu di sekolah inklusi. Istilah guru kelas biasa digunakan untuk sekolah dasar. Pada konsep sekolah inklusi, guru kelas tidak hanya memiliki tugas mengajar pada kelas tertentu, namun guru kelas juga memiliki tugas berkoordinasi dengan Guru Pendamping Khusus untuk menyusun Program Pembelajaran Individual khusus untuk peserta didik berkebutuhan khusus yang tergabung pada kelas tersebut. Guru kelas memiliki kewajiban menyediakan kegiatan pembelajaran untuk peserta didik berkebutuhan khusus dan peserta didik reguler. Beban materi belajar untuk peserta didik berkebutuhan khusus harus disediakan sesuai dengan kebutuhan dan kemampuan mereka.

b. Guru mata pelajaran

Guru mata pelajaran adalah guru yang mengajar mata pelajaran tertentu sesuai kualifikasi yang telah ditentukan. Istilah guru mara pelajaran biasa digunakan untuk SMP, SMA, dan SMK. Pada konsep sekolah inklusi, guru mata pelajaran memiliki tugas yang hampir sama dengan guru kelas pada tingkat sekolah dasar yaitu tidak hanya memiliki tugas mengajar pada mata pelajaran tertentu, namun juga memiliki tugas berkoordinasi dengan Guru Pendamping Khusus untuk menyusun Program Pembelajaran Individual khusus untuk peserta didik berkebutuhan khusus yang tergabung pada kelas mata pelajaran tersebut. Guru mata pelajaran juga memiliki kewajiban menyediakan kegiatan pembelajaran untuk peserta didik berkebutuhan khusus dan peserta didik reguler. Beban materi belajar untuk peserta didik berkebutuhan khusus harus disediakan sesuai dengan 
kebutuhan dan kemampuan mereka.

c. Guru pendamping khusus Guru pendamping khusus adalah guru yang memiliki kompetensi sarjana Pendidikan Luar Biasa atau Kependidikan yang memiliki keilmuan pendidikan khusus dengan tugas sebagai pendukung guru kelas dan atau guru mata pelajaran dalam memberikan pelayanan pendidikan khusus, intervensi, kompensatoris, sesuai kebutuhan peserta didik berkebutuhan khusus di sekolah inklusi. Dalam hal ini guru pendamping khusus harus mampu mengidentifikasi dan mengasesmen kemampuan dan kebutuhan peserta didik berkebutuhan khusus. Selanjutnya, dapat dikoordinasikan dengan guru kelas atau guru mata pelajaran agar dapat disusun program pembelajaran individual. Guru pendamping khusus juga harus mampu memberikan intervensi berupa layanan kompensatoris untuk membantu perkembangan lain seperti kemampuan komunikasi, sosial, emosional, dan perilaku.

\section{Asesmen}

Asesmen merupakan suatu kegiatan untuk menemukenali kondisi peserta didik, mencakup aspek: potensi, kemampuan, kebutuhan, dan karakteristik peserta didik berkebutuhan khusus dalam rangka menentukan program pembelajaran individual dan atau layanan intervensi untuk menunjang perkembangannya. Lebih daripada itu, asesmen juga bertujuan untuk menemukan keunggulan dan permasalahan belajar peserta didik, sehingga program pembelajaran individual yang disusun diharapkan sesuai dengan kebutuhan dan kemampuan peserta didik. Asesmen merupakan hal yang sangat penting dalam memberikan pelayanan untuk anak berkebutuhan khusus, termasuk dalam penyelenggaraan pendidikan inklusif. Dalam penduan penyelenggaraan pendidikan inklusif (PKLK, 2011) ditegaskan bahwa satuan pendidikan yang menyelenggarakan pendidikan inklusif wajib melaksanakan kegiatan identifikasi dan asesmen untuk semua peserta didik. Selanjutnya, proses identifikasi dan asesmen di sekolah inklusi dapat dilakukan dengan membentuk tim yang melibatkan beberapa komponen yaitu kepala sekolah, guru pendamping khusus, guru bk, dan guru kelas. Lebih daripada itu, sekolah dapat bekerja sama dengan tenaga ahli seperti psikolog, psikiater, terapis, atau dokter untuk 
menunjang proses pelaksanaan identifikasi dan asesmen.

\section{$\underline{\text { Kurikulum }}$}

Terdapat 3 jenis kurikulum yang diterapkan pada sistem pendidikan inklusif di Indonesia yaitu Kurikulum Standar Nasional, Kurikulum Akomodatif Dibawah Standar Nasional, dan Kurikulum Akomodatif Diatas Standar Nasional (PKLK, 2011). Kurikulum standar nasional merupakan kurikulum yang diterapkan pada seluruh peserta didik sesuai dengan standar yang diterapkan di seluruh sekolah secara nasional. Sedangkan kurikulum akomodatif merupakan kurikulum standar nasional yang telah disesuaikan dengan bakat, minat, potensi, kebutuhan dan kemampuan peserta didik berkebutuhan khusus. lebih daripada itu, kurikulum akomodatif dapat memiliki bobot di bawah ataupun di atas kurikulum standar nasional yang sebenarnnya, kurikulum akomodatif harus disusun sesuai dengan hasil identifikasi dan asesmen peserta didik agar dalam penerapannya dapat tepat sasaran sesuai dengan karakteristik, kebutuhan, dan kemampuan peserta didik. Penerapan kurikulum akomodatif dapat memanfaatkan model penyelarasan kurikulum yang dilakukan dalam bentuk Eskalasi,
Duplikasi, Modifikasi, Subtitusi, dan Omisi.

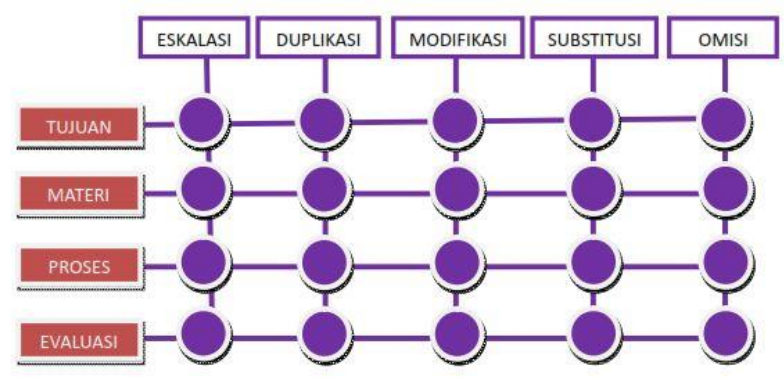

Gambar Model Kurikulum

(PKLK, 2011)

Sesuai dengan pengertiannya kurikulum eskalasi merupakan kurikulum yang disusun dengan menaikkan bobot materi pembelajaran baik dala segi tingkat kesulitan dan atau segi cakupan materi. Kurikulum eskalasi ini disediakan untuk memberikan pelayanan pendidikan khusus untuk peserta didik yang memiliki kecerdasan dan atau bakat istimewa. Tujuannya, dengan adanya kurikulum eskalasi dapat menunjang setiap potensi yang dimiliki peserta didik agar dapat berkembang secara optimal. Selanjutnya, kurikulum dengan model duplikasi merupakan kurikum yang diterapkan untuk peserta didik berkebutuhan khusus yang memiliki kemampuan akademik rata-rata atau sama seperti peserta didik reguler pada umumnya. Oleh karena itu, kurikulum model duplikasi dapat disebut sebagai kurikulum standar nasional yang diterapkan pada 
peserta didik berkebutuhan khusus. Dengan kata lain, peserta didik berkebutuhan khusus akan mendapatkan bobot materi pembelajaran yang sama dengan peserta didik reguler. Bentuk duplikasi pada model kurikulum ini dapat berbentuk duplikasi tujuan pembelajaran, duplikasi isi materi, duplikasi proses pelaksanaan pembelajaran, dan atau duplikasi proses evaluasi. Bentuk duplikasi tersebut harus disesuaikan dengan kebutuhan dan karakteristik peserta didik berkebutuhan khusus.

Lebih lanjut, kurikulum model modifikasi merupakan kurikulum yang dimodifikasi atau disesuaikan dari kurikulum standar nasional. Bentuk meodifikasi kurikulum memungkinkan sekolah untuk menurunkan bobot, menaikkan bobot, atau menyesuaikan bentuk kurikulum untuk anak berkebutuhan khusus. Seperti halnya kurikulum duplikasi, pada kurikulum modifikasi dapat menyesuaikan utjuan pembelajaran, isi materi, proses pelaksanaan pembelajaran, dan atau proses evaluasi. Tidak jauh berbeda pengertian pada model subtitusi, yangmana pada kurikulum ini memungkinkan sekolah untuk mengganti isi kurikulum standar nasional dengan materi lain yang sesuai dengan kondisi peserta didik berkebutuhan khusus. sedangkan kurikulum model omisi yaitu model kurikulum nasional yang telah dihilangkan sebagian atau secar keseluruhan karena tidak memungkinkan untuk diterapkan pada peserta didik berkebutuhan khusus.

\section{Pengelolaan Kelas}

Pada aspek pengelolaan kelas, sekolah inklusi dapat menerapkan sistem pengelolaan Kelas Reguler Penuh, Kelas Reguler dengan GPK, dan Kelas Khusus. Kelas reguler penuh melaksanakan kegiatan pembelajaran yang diikuti oleh peserta didik berkebutuhan khusus dan peserta didik reguluer. Penyelenggaraan kelas reguler penuh ini, ditujukan untuk peserta didik berkebutuhan khusus yang dapat menyeseuaikan diri dengan kondisi kelas yang diikuti oleh peserta didik reguler, dalam arti mereka tidak memiliki permaslahan spesifik yang dapat mengganggu proses belajar mengajar berlangsung. Lebih daripada itu, kelas reguler penuh menerapkan kurikulum standar nasional yang berlaku bagi semua peserta didik. Kelas reguler dengan GPK diikuti oleh peserta didik berkebutuhan khusus yang belajar bersama dengan peserta didik reguler menggunakan kurikulum standar nasional, namun peserta didik berkebutuhan khusus 
memperoleh layanan khusus dari GPK. Hal ini dimaksudkan untuk membantu peserta didik berkebutuhan khusus yang memiliki permasalahan tertentu yang membuat mereka kesulitan untuk menyuaikan diri dengan proses belajar mengajar. Sedangkan kelas khusus diikuti oleh peserta didik berkebutuhan khusus yang kegiatan belajarnya dipisahkan dengan peserta didik reguler (Irvan, 2017). Di lingkup kelas khusus, disediakan Ruang Sumber yang berfungsi sebagai fasilitas penunjang untuk memberikan layanan akademik maupun layanan non akademik (kompensatoris) untuk peserta didik berkebutuhan khusus dalam kelas khusus.

\section{Aksesibilitas}

Sesuai dengan Kepmen PU No. 30 tahun 2006 bahwa setiap bagunan fasilitas umum harus memenuhi standar aksesibilitas untuk anak berkebutuhan khusus. Seperti halnya fasilitas umum lain, sekolah inklusi juga memiliki kewajiban menciptakan layanan di setiap gedung agar ramah terhadap peserta didik berkebutuhan khusus. Adapun aksesibilitas gedung harus meliputi empat unsur fasilitas dan aksesibilitas yaitu keselamatan, kemudahan, kegunaan, dan kemandirian.
2. Interpretasi Masyarakat Tentang Pendidikan Inklusif dan Implementasinya

a. Anggapan dan Tanggapan Tentang Sekolah Inklusi

Penerapan pendidikan inklusif sejatinya mampu mendorong perkembangan kualitas pendidikan bagi warga negara. Memiliki tujuan luhur demi memenuhi hak setiap warga negara agar mendapat layanan pendidikan dan memenuhi program wajib belajar, pendidikan inklusif bergerak cepat merambah setiap kabupaten dan kota di Indonesia. Wawasan baru bagi masyarakat tentang pendidikan inklusif, berawal dari opini negatif sampai dengan dukungan terbaik muncul di kalangan masyarakat, bahkan warga sekolah yang terlibat. Berdasarkan hasil wawancara dengan guru pendamping khusus di sejumlah sekolah inklusi di Surabaya dan Sidoarjo, pada awal tahun-tahun awal tidak sedikit sekolah yang justru banyak kehilangan jumlah peserta didik setelah ditunjuk menjadi sekolah inklusi oleh pemerintah. Hal itu terjadi karena pandangan negatif masyarakat muncul dengan menyatakan bahwa "Sekolah ini sekarang jadi mirip SLB, banyak siswa cacat masuk sini". Namun, kebijakan memaksa masyarakat untuk sulit memilih. 
Pemerintah telah menerapkan kebijakan bahwa setiap kecamatan wajib memiliki minimal satu sekolah inklusi, seiring dengan hal tersebut pandangan masyarakat berangsur menjadi positif. Lalu bagimana dengan tenaga pendidik? Tidak berbeda dengan masyarakat awam, tenaga pendidik secara umum tidak memiliki wawasan khusus tentang pendidikan bagi anak berkebutuhan khusus. Berdasarkan keterangan guru pendamping khusus dua SMK di Sidoarjo yang ditunjuk menjadi SMK Inklusi, lebih banyak guru mata pelajaran yang enggan bekerjasama dan lebih repot karena menyusun PPI untuk peserta didik berkebutuhan khusus.

Namun daripada itu, telah berangsur membaik anggapan masyarakat tentang sekolah inklusi dengan menyatakan bahwa sekolah inklusi itu ada untuk menghilangkan diskriminasi bagi setiap peserta didik berkebutuhan khusus. Lebih daripada itu, sedikit demi sedikit sekolah swasta mengajukan nama untuk menerapkan sistem pendidikan inklusif. Tercatat lebih dari lebih dari 80 sekolah negeri dan swasta yang tersebar di setiap kecamatan di Surabaya resmi menyelenggarakan pendidikan inklusif. b. Perkembangan

Pendidikan Inklusif

Euforia masyarakat tentang penerapan pendidikan inklusif kian melambung, diiringi dengan pertumbuhan jumlah sekolah yang menyelenggarakan pendidikan inklusif semakin meningkat. Bahkan, undang-undang no.8 tahun 2016 telah mendorong pendidikan inklusif pada tingkat universitas dan telah dibuktikan dengan munculnya Pusat Layanan Disabilitas di beberapa universitas di Indonesia. Fakta tersebut menunjukkan perkembangan ke arah positif dalam bidang layanan pendidikan bagi anak berkebutuhan khusus. Namun demikian bukan berarti pemerintah dapat meninggalkan sejumlah program yang harus diterapkan dari segi implementasi pendidikan inklusif, sebagai contoh aksesibilitas, pemerataan, dan tenaga ahli.

Berdasarkan pada tujuan awal pendidikan inklusif diterapkan adalah untuk mengurangi kesenjangan wajib belajar bagi anak berkebutuhan khusus di pelosok daerah. Namun implementasi pendidikan inklusif saat ini semakin menjamur di wilayah perkotaan. Sebaliknya, berdasarkan hasil observasi yang dilakukan di Kabupaten 
Bojonegoro, Tuban, dan Lamongan masih belum menjalankan program pemerintah yang mewajibkan sekolah inklusi di tiap kecamatan.

Penerapan pendidikan inklusif sesmestinya tidak hanya mengubah status sekolah reguler menjadi inklusi, namun juga harus diiringi dengan pengembangan aksesibilitas untuk siswa berkebutuhan khusus. Meskipun Kepmen PU No. 30 tahun 2006 tentang aksesibilitas telah diperkuat dengan terbitnya UU. No.8 tahun 2016, tercatat berdasarkan hasil observasi secara acak di 10 sekolah inklusi berbagai tingkatan di Surabaya dan Sidoarjo tidak satupun memiliki sarana prasarana yang aksesibel bagi peserta didik berkebutuhan khusus (Borodkina, 2013).

Pendidikan inklusif semestinya dapat diselenggarakan dengan baik di suatu sekolah jika terdapat tenaga pendidik yang secara khusus merupakan tenaga ahli yang memiliki kompetensi dalam bidang pendidikan khusus. Guru pendidikan khusus merupakan bagian yang sangat penting demi suksesnya penyelenggaraan pendidikan inklusif di suatu sekolah. Sebab guru pendidikan khusus memiliki peran sebagai guru pendamping khusus, dan berkoordinasi dengan setiap warga sekolah untuk menumbuhkan budaya yang inklusif dalam lingkungan sekolah tersebut (Borodkina, 2013). Namun demikian, tidak tampak fungsi pendampingan dari pemerintah yang menunjukkan solusi terhadap permasalahan tersebut. Sehingga bagi daerah, kabupaten, atau kota kecil tidak terpantau progres implementasi pendidikan inklusif.

Berdasarkan permasalahanpermasalahan tersebut dapat kita tarik benang merah, bahwasanya dalam penerapan pendidikan inklusif tidak dapat serta merta dilaksanakan hanya dengan menunjuk sekolah yang bermutu dan melaksanakan sosialisasi. Namun lebih daripada itu, bahwa penerapan pendidikan inklusif saat ini memerlukan fungsi pengawasan, pendampingan, dan evaluasi. Hal ini demi menunjang progres yang lebih baik dalam rangka menumbuhkan kesadaran pendidikan, budaya masyarakat, serta lingkungan inklusif yang ramah terhadap anak berkebutuhan khusus.

\section{SIMPULAN}

Pendidikan inklusif merupakan pendidikan yang mengikutsertakan anak berkebutuhan khusus untuk belajar dan beraktivitas bersama dengan anakanak lain dalam satu lingkungan sekolah yang sama. Penerapan pendidikan 
inklusif di Indonesia membawa dampak baik terhadap wawasan masyarakat yang semakin terbuka akan adanya hakhak pendidikan bagi anak berkebutuhan khusus. Progres penerapan pendidikan inklusif di Indonesia dari segi kuantitas telah berkembang pesat. Berdasarkan tujuannya, pendidikan inklusif diterapkan demi menunjang tercapainya program wajib belajar bagi anak berkebutuhan khusus. Terselenggaranya sekolah inklusi diharapkan menjadi jawaban akan kurang tersebarnya SLB di setiap pelosok daerah. Namun demikian, tujuan tersebut kurang tercapai karena sekolah inklusi hanya terselenggara di pusat kota, bahkan menjamur di kota besar. Lebih lanjut sekolah inklusi yang teselenggara kurang mendapatkan pengawasan, pendampingan, bahkan tanpa adanya evaluasi untuk mengetahui kualitas dan progres penerapan pendidikan inklusif. Dengan demikian dapat ditarik kesimpulan bahwa, implementasi pendidikan inklusif membutuhkan pengawasan dari pemerintah di setiap sekolah yang ditunjuk untuk mengetahui progres penyelenggaraan pendidikan inklusif di suatu sekolah. Selanjutnya untuk menumbuhkan kesadaran warga sekolah selain membutuhkan tenaga pendidik yang berkompetensi dalam bidang pendidikan khusus, sekolah inklusi juga membutuhkan pendampingan agar dapat menumbuhkan budaya yang inklusif di lingkungan sekolah tersebut. Kemudian dibutuhkan suatu format evaluasi untuk mengontrol kualitas penyelenggaraan pendidikan inklusif. Dengan demikian penyelenggaraan pendidikan inklusif tidak hanya sukses dari segi kuantitas namun juga kualitas yang baik.

\section{PENGAKUAN}

Dalam bagian terakhir ini, Anda menyampaikan informasi yang diperlukan terkait asal naskah Anda. Misalnya, naskah pernah diperesentasikan dimana, naskah berasal dari skripsi, sampai dengan ucapan terima kasih kepada donor jika Anda meneliti dengan dana pihak lain. Naskah artikel ini ditulis berdasarkan hasil penelitian pendahuluan oleh penulis. Penelitian pendahuluan ini dilakukan untuk menunjang penelitian lanjutan. Penelitian pendahuluan dilakukan di Kabupaten Sidoarjo dan Kota Surabaya. Ucapan terima kasih disampaikan pada Universitas PGRI Adi Buana Surabaya yang telah mendukung terlaksananya kegiatan penelitian dan penulisan artikel ini. Selanjutnya, ucapan terima kasih juga kami sampaikan kepada Direktorat Riset dan Pengabdian Masyarakat, Direktorat Jenderal Penguatan Riset dan Pengembangan, KEMENRISTEKDIKTI selaku pihak yang mendanai terlaksananya kegiatan penelitian dan penulisan artikel ini. 


\section{DAFTAR PUSTAKA}

Goltsman, S. M., \& Iacofano, D. S. (2007). The inclusive city: design solutions for buildings, neighborhoods and urban spaces. Berkeley, Calif.: MIG Communications.

Abosi, Okey \& Koay, TL. (2008). Attaining Development Goal of Chldren with Disabilities: Implication for Inclusive Education. International Journal of Special Education, Vol. 23, Number 3.

Borodkina, Olga. (2013). Problem of The Inclusive Professional Education in Russia. PROCEDIA, 140, 542-546.

Choiri, Abdul Salim \& Munawir Yusuf. (2009). Pendidikan Anak Berkebutuhan Khusus Secara Inklusif. Surakarta: Inti Media.

Irvan, Muchamad. (2017). Pengetahuan Mahasiswa PG-PAUD UNIPA Surabaya Tentang Pendidikan Inklusif. BUANA PENDIDIKAN, 13 No.24, 155-164.

Nasichin. (2001). Kebijakan Direktorat Pendidikan Luar Biasa. REHABILITASI \& REMEDIAL, 11, 2.

O'Neil, John. (1994). "Can Inclusive Work? A Conversation with Jim Kauffman and Mara Sapon-Shevin". Educational Leadership.

PKLK. 2011. Pedoman Umum Penyelengaraan Pendidikan Inklusif. Jakarta: Kementrian Pendidikan dan Kebudayaan.
Smith, David. (2006). Inklusi, Sekolah yang Ramah untuk Semua. (Terjemahan). Bandung: Penerbit Nuansa. , Permendiknas No. 70 Tahun 2009 Tentang Pendidikan Inklusif Bagi Peserta Didik yang Memiliki Kelainan dan Memiliki Potensi Kecerdasan dan/atau Bakat Istimewa. Kepmen PU No. 30 Tahun 2006 Tentang Pedoman Teknis Fasilitas dan Aksesibilitas Pada Bangunan Gedung dan Lingkungan. 